\title{
PENYEBARAN HAMA KUTU PUTIH PEPAYA PARACOCCUS MARGINATUS Williams \& Granara de Willink (Hemiptera: Pseudococcidae) PADA BERBAGAI TANAMAN INANG DI KABUPATEN ENDE
}

\author{
Yustina M.S.W.Pu'u \\ Staff Pengajar PS Agroekoteknologi Fak Pertanian Universitas Flores
}

\begin{abstract}
Papaya is one of the many horticultural commodities grown by farmers. In mid 2008, thousands of trees in the District Sukaraga papaya, Bogor Regency pests infestation papaya white and whole tree has been attacked. P. marginatus is polifag insects that attack several host plants, including tropical fruit crops and ornamental plants. This research aims to determine the spread of lice infestation in White Paracoccus marginatus Ende and type of host plants are attacked by pests Mite White Paracoccus marginatus. This study is useful to obtain information about the spread of pests P. marginatus in the district of Ende as a step in taking control measures, information to relevant agencies and farmers about the existence of pest P. marginatus in Ende district, and continued research on the existence of natural enemies and pests bioekologi P. marginatus.

Sampling study conducted in 21 sub-districts in NTT Propinsis Ende. The study was conducted from March - August 2011. Materials used in this study are plant pests Paracoccus marginatus, Alcohol 95\%. The tools used are a collection of bottles, brushes, a microscope, transparent plastic, paper labels, Thermo-Hygrometer, cool box, stationery and literature.

The results showed that the spread of pests P. marginatus were observed in 21 subdistricts in Ende found only in the District 2 District East Ende and Ndona. Papaya is attacked by P. marginatus have chlorotic leaves, young leaves to fall and prospective fruits and fruit and leaves are covered by these pests by stacking layers of wax until the drought ends up dead. intensity of damage caused by pests P. marginatus in the District of East Ende of $33.33 \%$ and $16.67 \%$ for Ndona District. The spread of pests P. marginatus in the district of Ende found at two locations namely Ende Ende District East and District Ndona. Types of host plants are attacked by pests P. marginatus is Papaya plants.
\end{abstract}

Kata Kunci: papaya, Paracoccus marginatus

\section{PENDAHULUAN}

Pepaya merupakan salah satu komoditi hortikultura yang banyak dibudidayakan oleh petani. Buah pepaya sangat digemari oleh semua lapisan masyarakat dan tersedia sepanjang musim. Bagian tanaman yang dapat dmanfaatkan untuk konsumsi langsung adalah bagian buah, sedangkan bunga dan daun digunakan untuk sayuran. Pepaya memiliki kandungan vitamin, mineral, dan serat.

Indonesia merupakan salah satu negara produsen buah pepaya selain Brazil, Meksiko, India, dan Zaire. Luas lahan panen pepaya di Indonesia pada tahun 2007 mencapai 7.984 ha dengan hasil produksi mencapai 621.524 ton 
(Dirjen Hortikultura, 2009). Pada pertengahan tahun 2008, ribuan batang pohon pepaya di Kecamatan Sukaraga, Kabupaten Bogor terserang hama kutu putih dan seluruh pohon pepaya telah terserang. Kondisi ini mengakibatkan kerugian yang besar sehingga intensitas panen menurun akibat produktivitas tanaman yang terus menurun dengan kematian tanaman. Laporan Direktorat Jenderal Hortikultura (2008), bahwa hama kutu putih pepaya Paracoccus marginatus telah terdeteksi di Kabupaten dan Kota Bogor, Kabupaten Sukabumi, Depok Propinsi Jawa Barat , DKI Jakarta, dan Banten. Menurut Sartiami et al., (2009), kutu putih pepaya telah ditemukan di empat Kabupaten yakni Kabupaten Bogor, Cianjur, Sukabumi, Tangerang, dan Bali yang mengakibatkan kerusakan yang meluas pada tanaman buah-buahan dan tanaman hias seperti pepaya, kamboja, kembang sepatu, alamanda, dan puring. Dinas Pertanian Kabupaten Boyolali (2009) melaporkan bahwa hingga akhir bulan Oktober 2009, tanaman pepaya yang terserang hama kutu putih atau $P$. marginatus di wilayah Kabupaten Boyolali mencapai 252.375 pohon dari populasi sebanyak 443.910 pohon pepaya dan tersebar di 7 wilayah kecamatan sentra penghasil pepaya di Boyolali. Sedangkan di Balikpapan, Kalimantan Timur, dilaporkan sudah 30 $\%$ pepaya terserang. Hasil pengamatan menunjukkan bahwa, hama ini awalnya menyerang pepaya, tetapi kini menyerang singkong, tomat, dan jarak pagar (Dinas Pertanian Boyolali, 2009).

$P$. marginatus merupakan serangga polifag yang menyerang beberapa tanaman inang, termasuk tanaman buah tropis dan tanaman hias. Hama ini merupakan serangga asli yang berasal dari wilayah Neotropik seperti Belize, Costa Rica, Guatemala, dan Meksiko (Miller \& Miller, 2002). Di daerah asalnya, serangga ini tidak menjadi masalah serius karena terdapat musuh alami endemik di wilayah tersebut. $P$. marginatus biasanya hidup bergerombol sampai puluhan ribu ekor. Tubuh hama kutu putih yang satu ini licin seperti berselaput lilin dan merusak dengan cara mengisap cairan pada tanaman. Hama ini menyerang pada semua bagian tanaman mulai dari buah sampai pucuk. Serangan pada pucuk menyebabkan daun kerdil dan keriput seperti terbakar. Hama ini juga menghasilkan embun madu yang kemudian ditumbuhi cendawan jelaga, sehingga permukaan tanaman yang diserang akan berwarna hitam. Hama ini memiliki kurang lebih 50 tanaman inang antara lain Hibiscus spp, Acalypha, Plumeria, Citrus spp, Persea Americana, Solanum melongena, Zea mays, Acacia, dan lain-lain ((Alison Walker, Marjorie Hoy dan Dale Meyerdirk, 2003).

Kabupaten Ende merupakan salah satu daerah yang membudidayakan tanaman pepaya baik untuk komersial maupun konsumsi. Tanaman pepaya banyak dibudidayakan walaupun tidak dalam hamparan yang luas, tetapi ditumpangsari dengan tanaman yang lain. Hasil pengamatan yang dilakukan pada Bulan Oktober 2010, menunjukkan bahwa pepaya yang ada di beberapa lokasi telah terserang hama $P$. marginatusI. Hama ini pertama kali ditemukan menyerang pada tanaman pepaya dan srikaya. Keberadaan hama $P$. marginatus pada tanaman pepaya menjadi ancaman bagi produksi pepaya dan tanaman lain yang juga merupakan inang hama tersebut. Untuk mengatasi permasalahan hama tersebut, maka perlu dilakukan upaya preventif untuk menekan penyebaran hama $P$. marginatus. Sampai saat ini, belum ada informasi tentang keberdaan hama $P$. marginatus di Kabupaten Ende, 
sehingga dilakukan kajian awal tentang penyebaran hama kutu putih pepaya Paracoccus marginatus Williams \& Granara de Willink (Hemiptera: Pseudococcidae) pada berbagai tanaman inang di kabupaten Ende.

Penelitan ini bertujuan untuk mengetahui Penyebaran serangan hama Kutu Putih Paracoccus marginatus di Kabupaten Ende dan Jenis tanaman inang yang terserang hama Kutu Putih Paracoccus marginatus. Penelitian ini bermanfaat untuk mendapatkan informasi tentang penyebaran hama $P$. marginatus di Kabupaten Ende sebagai langkah dalam pengambilan tindakan pengendalian, informasi bagi dinasdinas terkait dan petani tentang keberadaan hama $P$. marginatus di Kabupaten Ende, dan penelitian lanjutan tentang keberadaan musuh alami dan bioekologi hama $P$. marginatus.

\section{BAHAN DAN METODE}

Pengambilan sampel penelitian dilaksanakan di 21 Kecamatan di Kabupaten Ende Propinsis NTT. Penelitian ini dilaksanakan dari bulan Maret - Agustus 2011. Bahan yang digunakan dalam penelitian ini adalah tanaman yang terserang hama Paracoccus marginatus, Alkohol 95\%. Alat yang digunakan adalah botol koleksi, kuas, mikroskop, plastik transparan, kertas label, ThermoHygrometer, cool box, alat tulis menulis dan literatur.

\section{Pelaksanaan Penelitian}

Penentuan lokasi sampel. Lokasi sampel untuk pengamatan penyebaran serangan hama $P$. marginatus dilakukan di 21 Kecamatan Kabupaten Ende.

\section{Pengambilan sampel tanaman.}

Pengambilan sampel tanaman (buah, batang dan daun) yang diduga terserang hama $P$. marginatus pada berbagai tanaman inang dilakukan secara purposive sampling dan dilakukan setiap minggu selama 3 bulan. Sampelsampel tanaman yang didapat, dimasukkan dalam botol koleksi yang berisi alkohol $95 \%$ atau dalam cool box dan dibawa ke Laboratorium Fakultas Pertanian.

1. Pengamatan dan Identifikasi $P$. marginatus

Pengamatan $P$. marginatus dilakukan di Lapangan untuk melihat jenis tanaman inang yang terserang serta intensitas kerusakan dan Laboratorium untuk identifikasi. Identifikasi hama berdasarkan ciri morfloginya yang didasarkan pada beberapa literatur.

2. Pembuatan peta lokasi penyebaran hama $P$. marginatus Lokasi penyebaran hama $P$. marginatus dibuat dalam bentuk peta lokasi penyebaran.

\section{Parameter Pengamatan}

1. Lokasi serangan hama $P$. marginatus

2. Gejala serangan dan tanaman inang yang terserang $P$. marginatus

3. Intensitas kerusakan (\%)

Intensitas kerusakan dihitung dengan menggunakan rumus:

$$
I=\frac{a}{a+b} x 100 \%
$$

Dimana:

I = Intensitas Kerusakan

a = jumlah tanaman yan terserang

$\mathrm{b}=$ jumlah tanaman yang diamati

Dengan interval serangan:

a. Kerusakan 0\% - 25\%

Ringan

b. Kerusakan $30 \%-45 \%$

Sedang

c. Kerusakan 50\%-100\% :

Berat

Analisis data untuk identifikasi yaitu dengan cara mencocokkan morfologi spesimen yang ada 
dengan buku morfologi serangga karangan Borror (1970). Sedangkan untuk lokasi hama disajikan dalam bentuk peta.

\section{HASIL DAN PEMBAHASAN}

Penyebaran serangan Paracoccus marginatus di Kabupaten Ende
Hasil penelitian menunjukkan bahwa penyebaran serangan hama $P$. marginatus yang diamati pada 21 Kecamatan di Kabupaten Ende hanya terdapat di 2 Kecamatan yakni Kecamatan Ende Timur dan Ndona (Gambar 1)

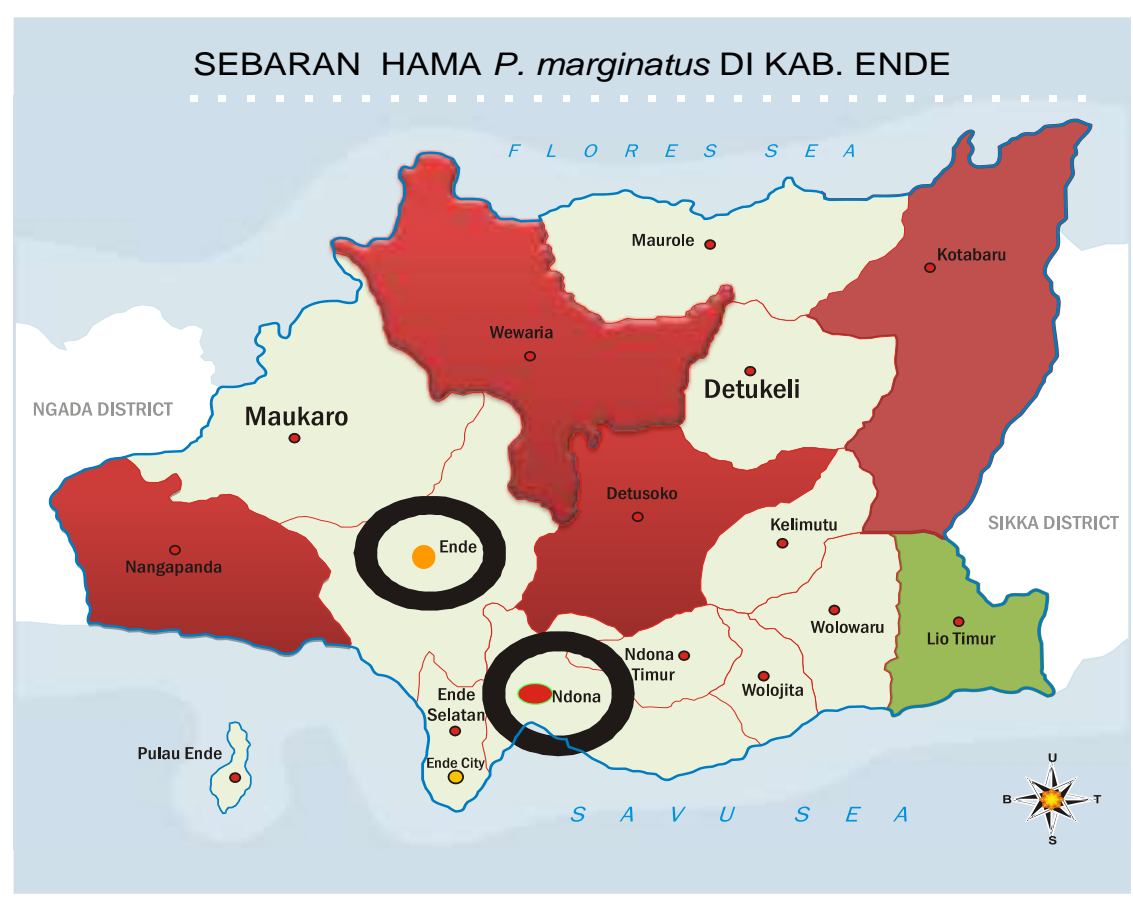

Gambar 1. Peta Sebaran Hama P. marginatus di Kabupaten Ende

Penyebaran serangan hama $P$. marginatus di 2 kecamatan (Ende Timur dan Ndona) diduga masuk melalui bibit pepaya yang berasal dari luar Kabupaten Ende. Hal ini disebabkan karena lokasi kedua kecamatan ini berdekatan dengan pasar, sehingga diduga hama tersebut masuk melalui bibit pepaya yang didatangkan dari luar wilayah Kabupaten Ende. Selain itu, juga disebabkan kedua lokasi ini termasuk daerah dataran rendah sehingga penyebaran hama menjadi lebih cepat tanpa adanya halangan yang didukung dengan faktor fisik seperti angin. Hal lain juga menyebabkan serangan hama $P$. marginatus di lokasi tersebut, karena penanaman tanaman pepaya tidak menggunakan jarak tanam yang tepat sehingga perpindahan instar 1 kutu putih sangat cepat dari satu tanaman ke tanaman yang lain. Jarak tanam memiliki hubungan yang erat kaitannya dengan proses pemencaran kutu putih pepaya. Stadium nimfa instar 1 aktif bergerak mencari tempat makan di sekitar tulang daun (Miller \& Miller, 2002). Proses pemencaran nimfa akan terbantu jika jarak tanam sempit.

Kecamatan lainnya yang tidak terserang hama kutu putih tersebut, kemungkinan disebabkan topografi wilayah yang berbukit-bukit sehingga menghalangi kemampuan terbang hama tersebut walaupun tertiup angin yang kencang. Selain itu, kemungkinan pada 
daerah-daerah tersebut bibit tanaman pepaya tidak diintroduksi dari luar tetapi masih menggunakan pepayapepaya lokal. Menurut Alison Walker, Marjorie Hoy dan Dale Meyerdirk (2003), penyebaran hama $P$. marginatus melalui tanaman yang terinfeksi, buahbuahan yang dibawa oleh manusia, melalui angin (instar 1), melalui serangga, dan melalui pakaian. Kutu pepaya memiliki ukuran yang sangat kecil serta tubuh yang ditutupi oleh lapisan lilin, sehingga mudah untuk diterbangkan oleh angin dan menempel pada bibit tanaman, pakaian serta alat pertanian. Selain itu, imago betina tidak memiliki sayap sehingga hanya dapat bergerak secara perlahan dalam jarak yang dekat atau bisa diterbangkan oleh angin.

\section{Gejala Serangan dan Tanaman inang} $P$. marginatus di Kabupaten Ende

Hasil penelitian menunjukkan bahwa, tanaman inang yang terserang hama $P$. marginatus di 2 lokasi yaitu tanaman pepaya (Gambar. 2 dan Gambar. 3). Hal ini disebabkan karena pepaya merupakan salah satu inang utama hama $P$. marginatus dan intensitas kerusakan paling besar juga pada tanaman pepaya. Tanaman inang $P$. marginatus sekitar 55 tanaman inang dari 25 genera, antara lain pepaya, singkong, Annona spp., kembang sepatu, alpukat, jeruk, kapas, tomat, terung, cabai, kacang-kacangan dan kacang polong, kentang manis mangga, cherry, ubi, ubi jalar, ochro, delima, jambu biji dan tanaman hias seperti kembang sepatu, jarak pagar, Allamanda, Acalypha, Hamelia, Kamboja dan Leander, dan gulma seperti sidadan (Alison Walker, Marjorie Hoy dan Dale Meyerdirk, 2003). Pepaya yang terserang $P$. marginatus daunnya mengalami klorosis, daun yang muda menjadi gugur dan calon buah serta buah dan daun tertutupi oleh hama tersebut dengan penumpukan lapisan lilin sampai ujungnya mengalami kekeringan hingga mati. Menurut Alison Walker, Marjorie Hoy dan Dale Meyerdirk (2003) bahwa Paracocus atau kutu putih pepaya memakan getah atau cairan tanaman dengan memasukkan stylets ke dalam epidermis daun, buah dan batang. tanaman yang terserang akan menunjukkan gejala klorosis, pengerdilan tanaman, deformasi daun, gugurnya daun muda dan calon buah, penumpukan lapisan lilin hingga mengakibatkan kematian. Serangan berat mampu mengakibatkan gejala kekeringan akibat habisnya cairan tanaman dan tebalnya penumpukan lapisan lilin. Kutu putih pepaya hanya makan bagian tanaman inang yang di atas tanah, yaitu daun dan buah.

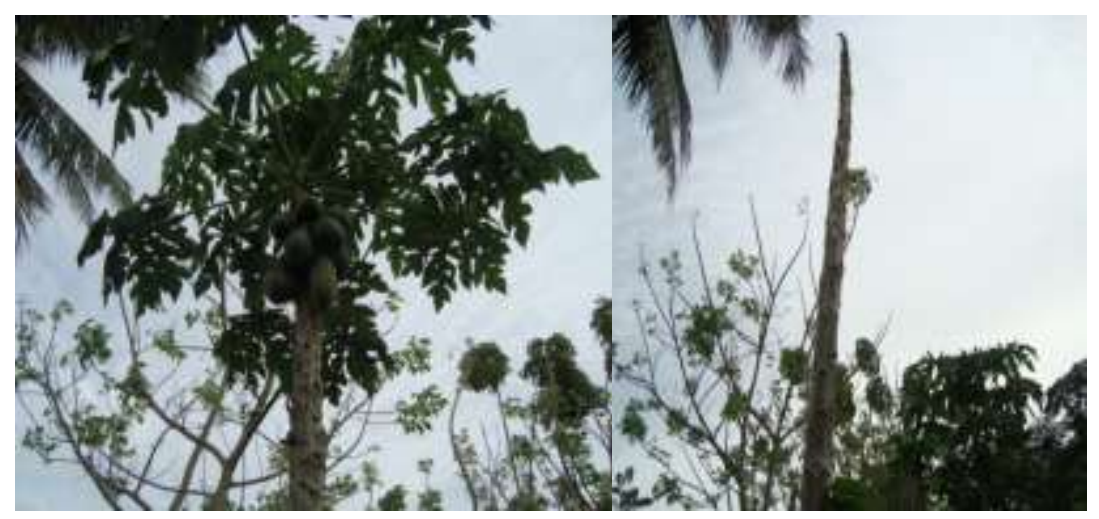

Gambar 2. Gejala Serangan Hama P. marginatus pada Buah Pepaya (Dokumentasi Pribadi, 2011) 


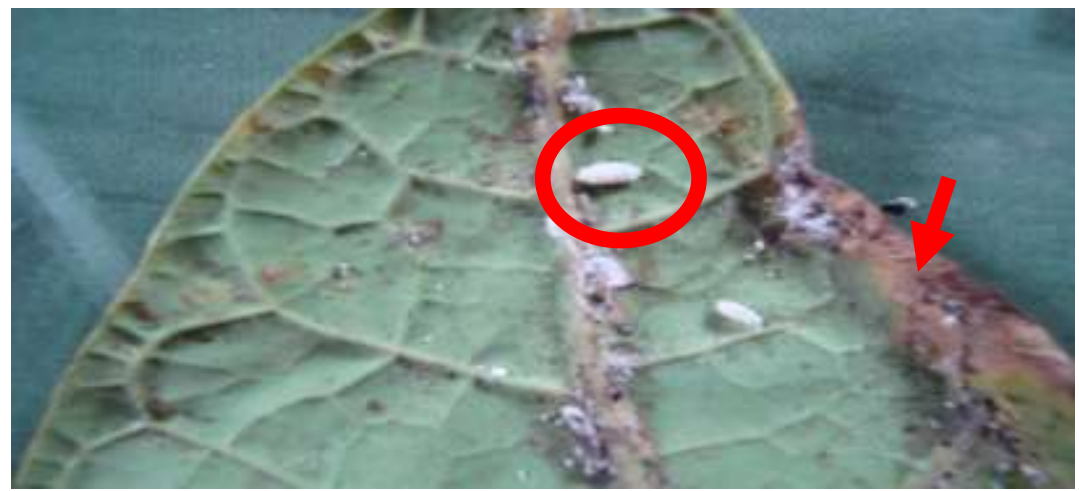

Gambar. 3 Gejala Serangan Hama P. marginatus pada daun Pepaya (Dokumentasi Pribadi, 2011)

$\begin{array}{lll}\text { Intensitas Kerusakan } \quad \boldsymbol{P} & \text { oleh hama } P . & \text { marginatus di } \\ \text { marginatus }(\%) & & \text { Kecamatan Ende Timur sebesar } \\ \text { Hasil penelitian menunjukkan } & 33,33 \% \text { dan Kecamatan Ndona } \\ \text { bahwa intensitas kerusakan yang } & \text { sebesar } 16,67 \% \text { (Tabel 1) }\end{array}$

Tabel 1. Intensitas Kerusakan hama $P$. marginatus

\begin{tabular}{cccc}
\hline No & Lokasi & Intensitas Kerusakan & $(\%)$ Kategori kerusakan \\
\hline 1 & Kecamatan Ende Timur & $33,33 \%$ & Sedang \\
2 & Kecamatan Ndona & $16,67 \%$ & Ringan \\
\hline
\end{tabular}

Intensitas serangan masih tergolong sedang dan ringan. Kondisi ini menunjukkan serangan hama $P$. marginatus di Kabupaten Ende populasinya sangat sedikit dan belum merugikan secara ekonomis. Kondisi ini dapat dilakukan pengendalian secara preventif dengan tidak memasukkan bibit pepaya dari luar daerah serta melakukan pengendalian secara fisik dan mekanik.

Tindakan preventif yang perlu dilakukan melalui kegiatan karantina untuk mencegah masuknya bibit pepaya dari luar Kabupaten Ende. Salah satu usaha untuk mencegah pemasukan, penyebaran dan meluasnya organisme penganggu tanaman (hama dan penyakit) berbahaya dari satu daerah ke daerah lainnya adalah dengan peraturan atau tindakan karantina. Tindakan karantina adalah tindakan dari Pemerintah untuk mencegah masuk atau tersebarnya organisme penganggu tanaman berbahaya berdasarkan peraturan Undang-Undang Nomor 2 Tahun 1961 tentang Pengeluaran dan Pemasukan Tanaman dan Bibit Tanaman yang merupakan landasan hukum pelaksanaan Karantina di Indonesia (Untung, 2006).

\section{SIMPULAN}

1. Penyebaran serangan hama $P$. marginatus di Kabupaten Ende ditemukan di 2 lokasi Kabupaten Ende yaitu Kecamatan Ende Timur dan Kecamatan Ndona.

2. Jenis tanaman inang yang terserang hama $P$. marginatus adalah tanaman Pepaya.

\section{UCAPAN TERIMA KASIH}

Pada kesempatan ini penulis ingin mengucapkan terima kasih kepada 
semua pihak yang telah membantu dengan caranya masing-masing dalam melengkapi tulisan ini.

\section{DAFTAR PUSTAKA}

Alison, W., Marjorie, H., Dale, M. 2003. Papaya Mealybug Paracoccus marginatus Williams and Granara de Willink (Insecta: Hemiptera: Pseudococcidae). University of Florida IFAS Extension: University of Florida Florida Department of Agriculture and Consumer Services, Division of Plant Industry and University of Florida.

Dinas Pertanian Kabupaten Boyolali. 2010. 252.375 Pepaya Terserang Kutu Putih.

http://boyolalikab.go.id/inde $\mathrm{x}$ 2.php?option=com_content $\& d o \_p d f=1 \& i d=224$

Direktorat Jendral Hortikultura. 2008. Waspada Serangan Kutu Putih pada Tanaman Pepaya. http://ditlin.hortikultura.dept an.go.id/index.php?option=c om_frontpage \&Itemid=1\&li mit=4\&limitstart $=4$.

Direktorat Jendral Hortikultura. 2009. Statistik produksi luas lahan panen dan hasil produksi 2003-2007 Tanaman Buah-buahan di Indonesia.

http://ditlin.hortikultura.dept an.go.id/index.php?option=c om_frontpage \&Itemid $=1 \&$ li mit $=4 \&$ limitstart $=4$.
Direktorat Perlindungan Tanaman Hortikultura. 2010. Kutu putih pada tanaman pepaya. http://ditlin.hortikultura.dept an.go.id/index.php?option $=\mathrm{c}$ om_frontpage \&Itemid $=1 \&$ li mit $=4 \&$ limitstart $=4$.

Friamsa, N. 2009. Biologi dan statistik demografi kutu putih pepaya paracoccus marginatus williams \& granara de willink (hemiptera: pseudococcidae) pada tanaman pepaya (carica papaya L). Bogor: Departemen Proteksi Tanaman Fakultas Pertanian Institut Pertanian Bogor.

Miller DR, Williams DJ, Hamon AB. 1999. Notes on a new mealybug (Hemiptera: Coccoidea: Pseudococcidae) pest in Florida and the Caribbean: the papaya mealybug, Paracoccus marginatus Williams and Granara de Willink. Insecta Mundi 13: (3-4).

Miller, DR., Miller, GL. 2002. Redescription of Paracoccus marginatus Williams and Granara de Willink (Hemiptera: Coccidae: Pseudococcidae)

Untung, K. 2006. Pengantar Pengelolaan Hama Terpadu. Edisi Kedua. Yogyakarta: Gadjah Mada University.

Williams DJ, Granara de Willink MC. 1992. Mealybugs of Central and South America. CAB International, UK, 644 pp. 
